\title{
Global Lifetime of Elemental Mercury Against Oxidation by Atomic Bromine in the Free Troposphere
}

\section{Citation}

Holmes, Christopher D., Daniel J. Jacob, and Xin Yang. 2006. Global lifetime of elemental mercury against oxidation by atomic bromine in the free troposphere. Geophysical Research Letters 33: L20808.

\section{Published Version}

doi:10.1029/2006GL027176

\section{Permanent link}

http://nrs.harvard.edu/urn-3:HUL.InstRepos:3743671

\section{Terms of Use}

This article was downloaded from Harvard University's DASH repository, and is made available under the terms and conditions applicable to Other Posted Material, as set forth at http:// nrs.harvard.edu/urn-3:HUL.InstRepos:dash.current.terms-of-use\#LAA

\section{Share Your Story}

The Harvard community has made this article openly available.

Please share how this access benefits you. Submit a story.

\section{Accessibility}




\title{
Global lifetime of elemental mercury against oxidation by atomic bromine in the free troposphere
}

\author{
Christopher D. Holmes, ${ }^{1}$ Daniel J. Jacob, ${ }^{1}$ and Xin Yang ${ }^{2}$ \\ Received 9 June 2006; revised 8 August 2006; accepted 31 August 2006; published 21 October 2006.
}

[1] We calculate the global mean atmospheric lifetime of elemental mercury $\left(\mathrm{Hg}^{0}\right)$ against oxidation by atomic bromine $(\mathrm{Br})$ in the troposphere by combining recent kinetic data for the $\mathrm{Hg}-\mathrm{Br}$ system with modeled global concentrations of tropospheric Br. We obtain a lifetime of 0.5-1.7 years based on the range of kinetic data, implying that oxidation of $\mathrm{Hg}^{0}$ by $\mathrm{Br}$ is a major, and possibly dominant, global sink for $\mathrm{Hg}^{0}$. Most of the oxidation takes place in the middle and upper troposphere, where $\mathrm{Br}$ concentrations are high and where cold temperatures suppress thermal decomposition of the $\mathrm{HgBr}$ intermediate. This oxidation mechanism is consistent with mercury observations, including in particular high gaseous $\mathrm{Hg}$ (II) concentrations in Antarctic summer. Better freetropospheric measurements of bromine radicals and further kinetic study of the $\mathrm{Hg}-\mathrm{Br}$ system are essential to more accurately assess the global importance of $\mathrm{Br}$ as an oxidant of atmospheric $\mathrm{Hg}^{0}$. Citation: Holmes, C. D., D. J. Jacob, and X. Yang (2006), Global lifetime of elemental mercury against oxidation by atomic bromine in the free troposphere, Geophys. Res. Lett., 33, L20808, doi:10.1029/2006GL027176.

[2] Mercury is present in the atmosphere principally in its elemental form, $\mathrm{Hg}^{0}$, which can be transported globally, as indicated by the uniformity of its atmospheric concentration. $\mathrm{Hg}^{0}$ is eventually oxidized to $\mathrm{Hg}$ (II), which may cycle back to $\mathrm{Hg}^{0}$, partition into atmospheric water, or react with surfaces. The latter two processes contribute to mercury deposition and accumulation in ecosystems. Some deposited mercury is subsequently reduced and re-emitted as $\mathrm{Hg}^{0}$. Unlike other heavy metals, mercury transits among surface reservoirs primarily through atmospheric fluxes [Mason and Sheu, 2002]. Therefore, understanding the atmospheric redox chemistry of mercury is critical to determining source-receptor relationships of this toxic element.

[3] Current models assume that gaseous hydroxyl radicals $(\mathrm{OH})$ and gaseous ozone $\left(\mathrm{O}_{3}\right)$ are the main global oxidants of $\mathrm{Hg}^{0}$ [e.g., Bergan and Rodhe, 2001]. Laboratory kinetic studies imply that the global mean lifetime of $\mathrm{Hg}^{0}$ is 120-210 days against oxidation by $\mathrm{OH}$ [Sommar et al., 2001; Pal and Ariya, 2004a] and 60-1500 days against oxidation by $\mathrm{O}_{3}$ [Hall, 1995; Pal and Ariya, 2004b]. However, in light of the expected rapid thermal dissociation of $\mathrm{HgOH}$ [Goodsite et al., 2004], Calvert and Lindberg

\footnotetext{
${ }^{1}$ Department of Earth and Planetary Sciences and Division of Engineering and Applied Sciences, Harvard University, Cambridge, Massachusetts, USA. UK.

${ }^{2}$ Centre for Atmospheric Science, University of Cambridge, Cambridge,
}

Copyright 2006 by the American Geophysical Union. 0094-8276/06/2006GL027176\$05.00
[2005] concluded that oxidation of $\mathrm{Hg}^{0}$ by $\mathrm{OH}$ is much slower than reported by the above studies and is insignificant under atmospheric conditions. Atmospheric observations constrain the residence time of total atmospheric mercury $\left(\mathrm{Hg}^{0}+\mathrm{Hg}(\mathrm{II})\right)$ to $0.5-2$ years [Schroeder and Munthe, 1998], which places an upper limit on the lifetime of $\mathrm{Hg}^{0}$ against oxidation (depending on competition between reduction and deposition of $\mathrm{Hg}(\mathrm{II}))$. Ozone alone cannot be the main oxidant of $\mathrm{Hg}^{0}$ because it explains neither the observed seasonal variation of $\mathrm{Hg}^{0}$ and dissolved $\mathrm{Hg}(\mathrm{II})$ in rainwater [Bergan and Rodhe, 2001; Selin et al., 2006], nor the observed diurnal cycle of gaseous $\mathrm{Hg}(\mathrm{II})$ [Laurier et al., 2003; Hedgecock et al., 2005]. These observations imply that oxidation of $\mathrm{Hg}^{0}$ must be photochemically mediated.

[4] Goodsite et al. [2004] developed a homogeneous mechanism for $\mathrm{Hg}-\mathrm{Br}$ chemistry in the troposphere based on theoretical kinetic calculations, and showed that gasphase oxidation of $\mathrm{Hg}^{0}$ by $\mathrm{Br}$ atoms could explain mercury depletion events (MDEs) in the Arctic springtime boundary layer. They suggested that this mechanism would be important more generally in the marine boundary layer and on the global scale. Lin et al. [2006] suggested that $\mathrm{Hg}-\mathrm{Br}$ chemistry is also significant in the upper troposphere. We present here a quantitative analysis of the global lifetime of $\mathrm{Hg}^{0}$ against oxidation by tropospheric $\mathrm{Br}$ by combining the mechanism of Goodsite et al. [2004] with Br concentrations from a global 3-D simulation of tropospheric bromine chemistry [Yang et al., 2005] as well as updated kinetic data. We find that oxidation by $\mathrm{Br}$ in the middle and upper troposphere could be an important sink for $\mathrm{Hg}^{0}$, and that the mechanism yields an atmospheric lifetime of $\mathrm{Hg}^{0}$ consistent with observational constraints.

[5] Recent observations indicate that the free troposphere contains significant BrO. Satellite instruments (GOME and SCIAMACHY) observe $\mathrm{BrO}$ columns with $1-4 \times$ $10^{13}$ molecules $\mathrm{cm}^{-2}$ in excess of the known stratospheric abundance [Salawitch et al., 2005; Sinnhuber et al., 2005]. This corresponds to $0.5-2 \mathrm{pptv} \mathrm{BrO}$ distributed throughout the tropospheric column. Balloon measurements in the northern mid-latitudes and tropics give independent evidence for $0.5-2 \mathrm{pptv} \mathrm{BrO}$ in the troposphere [Fitzenberger et al., 2000; Pundt et al., 2002; Van Roozendael et al., 2002]. Tropospheric sources include activation from sea salt; oxidation and photolysis of bromocarbons; transport from the stratosphere; and recycling from reservoir species $\left(\mathrm{Br}_{2}, \mathrm{HOBr}, \mathrm{BrNO}_{2}, \mathrm{BrONO}_{2}, \mathrm{HBr}\right)$ by homogeneous and heterogeneous processes [von Glasow et al., 2002; Platt and Honninger, 2003; Yang et al., 2005; Salawitch, 2006].

[6] Some ground-based observations have found lower abundances of tropospheric BrO. Schofield et al. [2004] found an upper limit of $1.2 \times 10^{13}$ molecules $\mathrm{cm}^{-2}$ in the 
Table 1. Rate Constants for Oxidation of $\mathrm{Hg}^{0}$ by $\mathrm{Br}$ Under Atmospheric Conditions

\begin{tabular}{|c|c|c|c|}
\hline & Rate Constant $\mathrm{t}^{\mathrm{a}}$ & Conditions & Reference \\
\hline$k_{1}$ & $\begin{array}{l}3.2 \times 10^{-12} \\
1.0 \times 10^{-12} \exp (209 / T) \\
1.1 \times 10^{-12}(T / 298)^{-2.37} \\
3.0-9.7 \times 10^{-13} \\
1.5 \times 10^{-32}(T / 298)^{-1.86}[\mathrm{M}]\end{array}$ & $\begin{array}{l}1 \mathrm{~atm}, 298 \mathrm{~K} \\
1 \mathrm{~atm}^{\mathrm{b}} \\
1 \mathrm{~atm}^{\mathrm{b}} \\
1 \mathrm{~atm}, 298 \mathrm{~K}^{\mathrm{c}}\end{array}$ & $\begin{array}{l}{[\text { Ariya et al., 2002] }} \\
{[\text { Khalizov et al., 2003] }} \\
\text { [Goodsite et al., 2004] } \\
{[\text { Donohoue et al., 2006] }} \\
{[\text { Donohoue et al., 2006] }}\end{array}$ \\
\hline$k_{2}$ & $1.2 \times 10^{10} \exp (-8357 / T)$ & $1 \mathrm{~atm}$ & [Goodsite et al., 2004] \\
\hline$k_{3, \mathrm{Br}}$ & $\begin{array}{l}2.5 \times 10^{-10}(T / 298)^{-0.57} \\
3.0 \times 10^{-11} \\
1.2 \times 10^{-10}\end{array}$ & $\begin{array}{l}1 \text { atm, high } p \text { limit } \\
2 \text { body, } 298 \mathrm{~K}^{\mathrm{d}} \\
\text { high } p \text { limit, } 298 \mathrm{~K}\end{array}$ & $\begin{array}{l}{[\text { Goodsite et al., 2004] }} \\
{[\text { Balabanov et al., 2005 }} \\
\text { [Balabanov et al., } 2005\end{array}$ \\
\hline $\begin{array}{l}k_{3, \mathrm{OH}} \\
k_{4}\end{array}$ & $\begin{array}{l}2.5 \times 10^{-10}(T / 298)^{-0.57} \\
3.9 \times 10^{-11}\end{array}$ & 1 atm, high $p$ limit $^{\mathrm{e}}$ & $\begin{array}{l}\text { [Goodsite et al., 2004] } \\
\text { [Balabanov et al., 2005 }\end{array}$ \\
\hline
\end{tabular}

${ }^{a}$ Rate constants are in units of $\mathrm{cm}^{3}$ molecule ${ }^{-1} \mathrm{~s}^{-1}$, except for $k_{2}\left(\mathrm{~s}^{-1}\right) . T$ is temperature in K. [M] is the number density of air.

${ }^{b}$ We assume in our calculations that $k_{1}$ is in the low-pressure regime at $1 \mathrm{~atm}$, following Donohoue et al. [2006], and thus scale $k_{1}$ with [M].

'Unpublished data from Spicer et al. [2002] cited by Donohoue et al. [2006].

${ }^{\mathrm{d}}$ Rate constant in the absence of a third body, i.e., with stabilization of the activated complex solely by internal energy dissipation.

${ }^{\mathrm{e}}$ Inferred by analogy with $k_{3, \mathrm{Br}}$.

tropospheric column over Lauder, New Zealand. The maximum tropospheric column observed by Leser et al. [2003] during an Atlantic cruise was $0.6 \times 10^{13}$ molecules $\mathrm{BrO} \mathrm{cm} \mathrm{cm}^{-2}$. However, neither method was sensitive to $\mathrm{BrO}$ near the tropopause and therefore both could be reconciled with satellite observations if much of the satellites' nominally tropospheric $\mathrm{BrO}$ column were concentrated in the upper troposphere or lowermost stratosphere [Salawitch et al., 2005].

[7] Raofie and Ariya [2004] reported a gas-phase reaction of $\mathrm{BrO}$ with $\mathrm{Hg}^{0}$, but could not exclude the possibility of heterogeneous mechanisms in their experimental system. Homogeneous oxidation of $\mathrm{Hg}^{0}$ by $\mathrm{BrO}$ is endothermic and has a large energy barrier, making its atmospheric relevance unlikely [Balabanov and Peterson, 2003; Tossell, 2003]. However, oxidation by $\mathrm{Br}$ atoms is fast [Calvert and Lindberg, 2004; Goodsite et al., 2004]. Rapid chemical cycling between $\mathrm{BrO}$ and $\mathrm{Br}$ through $\mathrm{BrO}$ photolysis, selfreaction, and reaction with $\mathrm{NO}$, balanced by $\mathrm{Br}$ oxidation by $\mathrm{O}_{3}$, maintains $\mathrm{Br}: \mathrm{BrO}$ molar ratios of $0.01-2$ in the daytime troposphere [Platt and Janssen, 1995; Yang et al., 2005].

[8] We estimate here the global impact of atomic bromine on atmospheric oxidation of mercury through the two-step recombination reactions $(\mathrm{R} 1)+(\mathrm{R} 3)$, in competition with thermal dissociation (R2), following Goodsite et al. [2004]:

$$
\begin{gathered}
\mathrm{Hg}+\mathrm{Br} \stackrel{\mathrm{M}}{\longrightarrow} \mathrm{HgBr} \\
\mathrm{HgBr} \stackrel{\mathrm{M}}{\longrightarrow} \mathrm{Hg}+\mathrm{Br} \\
\mathrm{HgBr}+\mathrm{X} \stackrel{\mathrm{M}}{\longrightarrow} \mathrm{HgBrX} \quad(\mathrm{X}=\mathrm{Br}, \mathrm{OH})
\end{gathered}
$$

Other species (e.g., $\mathrm{X}=\mathrm{I}, \mathrm{O}_{2}$ ) may also contribute to reaction (R3) [Goodsite et al., 2004], but their effect is probably minor and we disregard them. The local lifetime of $\mathrm{Hg}^{0}$ against oxidation to chemically stable $\mathrm{Hg}(\mathrm{II})$ by (R1)(R3) is

$$
\tau_{\text {local }}=\frac{k_{2}+k_{3, \mathrm{Br}}[\mathrm{Br}]+k_{3, \mathrm{OH}}[\mathrm{OH}]}{k_{1}[\mathrm{Br}]\left(k_{3, \mathrm{Br}}[\mathrm{Br}]+k_{3, \mathrm{OH}}[\mathrm{OH}]\right)}
$$

Table 1 compiles literature values of $k_{1}, k_{2}$, and $k_{3}$. Reaction (R2) makes $\tau_{\text {local }}$ extremely sensitive to temperature, as $k_{2}$ doubles with every increase of $6 \mathrm{~K}$ (at 273K) [Goodsite et al., 2004]. There is limited information about the temperature $(T)$ and pressure $(p)$ dependences of $k_{1}$ and $k_{3}$. Donohoue et al. [2006] found that reaction (R1) is in the low pressure regime for $p \leq 1 \mathrm{~atm}$. Balabanov et al. [2005] reported high and low pressure limits for $k_{3, \mathrm{Br}}$, while Goodsite et al. [2004] found that the reaction is in the high pressure regime at $1 \mathrm{~atm}$.

[9] We calculate the global mean tropospheric lifetime of $\mathrm{Hg}^{0}$ against conversion to $\mathrm{Hg}$ (II) by (R1)-(R3) by integrating the loss over the troposphere using global distributions of $\mathrm{Br}, \mathrm{OH}$, and temperature, and assuming a uniform tropospheric $\mathrm{Hg}^{0}$ mixing ratio. For the $\mathrm{Br}$ concentration, we use monthly and zonally averaged values for four months (January, April, July, and October) from the global chemical transport model (CTM) of tropospheric bromine described by Yang et al. [2005] (Figure 1). This model includes budgets of the dominant bromocarbons and an empirical parameterization of halogen release from sea salt aerosols based on wind speed and observed bromide depletion. It simulates daytime tropospheric $\mathrm{BrO}$ columns $(0.2-$ $1.6 \times 10^{13}$ molecules $\mathrm{cm}^{-2}$ ) that are at the low end of the range of satellite observations; thus, the model provides a conservative, process-based estimate of bromine abundance. We use monthly mean temperatures from the NASA Goddard Earth Observing System (GEOS-4) assimilated meteorology for 1999. Monthly mean $\mathrm{OH}$ distributions are from a detailed simulation of tropospheric chemistry [Park et al., 2004]. $\mathrm{OH}$ and $\mathrm{Br}$ are present only during daylight, so we distribute the average monthly concentrations over the daytime hours.

[10] Partitioning among inorganic bromine species explains much of the variability of atomic $\mathrm{Br}$ in Figure 1 [Yang et al., 2005]. Br constitutes 10\% of inorganic bromine near the tropical tropopause, where $\mathrm{HBr}$ and $\mathrm{BrONO}_{2}$ photolyze rapidly, but less than $1 \%$ near the surface. Seasonal changes in $\mathrm{BrO}$ photolysis increase atomic $\mathrm{Br}$ concentrations in the summer hemisphere. Atomic $\mathrm{Br}$ is generally more abundant in the southern hemisphere than in the north because high wind speeds over the southern ocean drive large emissions from sea salt aerosols. 

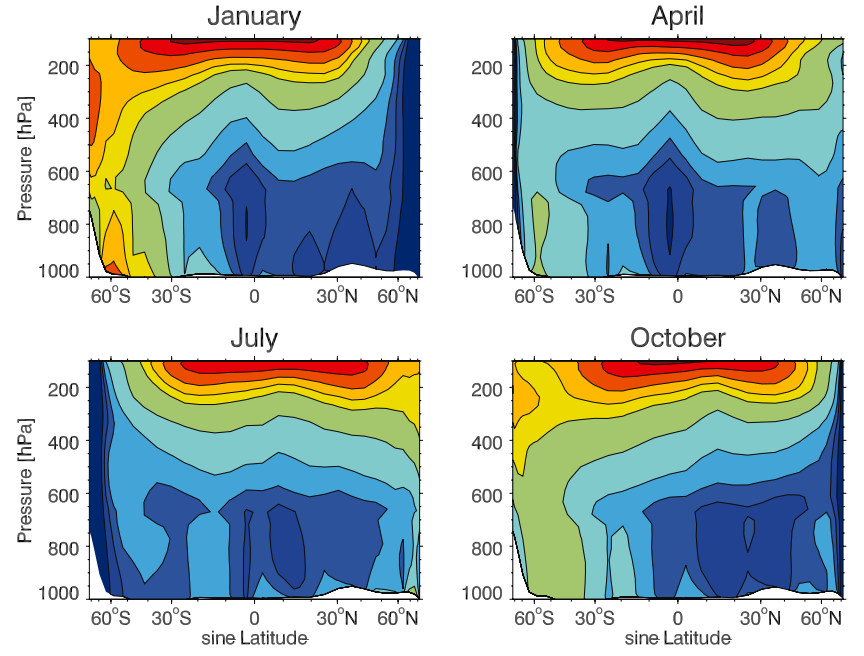

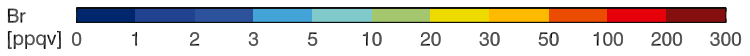

Figure 1. Monthly and zonally averaged atomic Br mixing ratios [ppqv] from the Yang et al. [2005] chemical transport model (CTM), which includes inorganic bromine released from sea salt and by photolysis and oxidation of bromocarbons. 1 ppqv $=10^{-15} \mathrm{~mol} \mathrm{~mol}^{-1}$.

[11] Figure 2 shows the lifetime of $\mathrm{Hg}^{0}$ against conversion to $\mathrm{Hg}(\mathrm{II})$ by (R1)-(R3), computed from Equation (1) for the months of January, April, July, and October. For this 'base case' estimate we use the most recent kinetic data with $T$ and $p$ dependences: $k_{1}$ from Donohoue et al. [2006]; $k_{3, \mathrm{Br}}$ and $k_{3, \mathrm{OH}}$ from Goodsite et al. [2004]; and $k_{2}$ calculated to maintain the $k_{1}: k_{2}$ balance [Goodsite et al., 2004].

[12] From Figure 2 we see that the lifetime of $\mathrm{Hg}^{0}$ is less than 300 days in all seasons near the tropical tropopause due to high $\mathrm{Br}$ concentrations and low temperatures (suppressing (R2)). This is consistent with recent aircraft observations of high concentrations of aerosol-bound mercury (presumably $\mathrm{Hg}(\mathrm{II})$ ) associated with bromine and iodine near the tropopause [Murphy et al., 2006]. Assuming a uniform mixing ratio of $\mathrm{Hg}^{0}$ up to the tropopause (taken as $150 \mathrm{hPa}$ in the tropics and $300 \mathrm{hPa}$ elsewhere), we find that $47 \%$ of $\mathrm{Hg}^{0}$ tropospheric oxidation occurs in the upper troposphere (above $500 \mathrm{hPa}$ ), 32\% in the middle troposphere $(800-500 \mathrm{hPa})$, and $21 \%$ in the lower troposphere. The lifetime we calculate for the northern mid-latitude boundary layer ( $>500$ days) is much longer than a previous lower bound of 160 days for the marine boundary layer in that region [Goodsite et al., 2004] mainly because our zonal-mean lifetime accounts for the lower $\mathrm{Br}$ abundances over land. The seasonal cycle in Figure 2 shows that despite the opposing influence of temperature, the increased concentrations of $\mathrm{Br}$ and $\mathrm{OH}$ in summer shorten $\tau_{\text {local }}$ relative to winter, in agreement with the observed seasonal cycle of $\mathrm{Hg}^{0}$ [e.g., Ebinghaus et al., 2002; Selin et al., 2006].

[13] Mass-weighted integration of the $\mathrm{Hg}^{0}$ loss rates $\left(1 / \tau_{\text {local }}\right)$ from Figure 2 yields a global mean tropospheric $\mathrm{Hg}^{0}$ lifetime, $\tau_{\text {global }}$, of 510 days against conversion to $\mathrm{Hg}(\mathrm{II})$ by (R1)-(R3). This is similar to current estimates of the lifetime of $\mathrm{Hg}^{0}$ against oxidation by ozone [e.g., Selin et al., 2006] and could account for a large part of the $\mathrm{Hg}^{0}$ loss within the $0.5-2 \mathrm{yr}$ observational constraint on the atmospheric lifetime of total mercury. We find that $\sim 85 \%$ of the $\mathrm{Hg}(\mathrm{II})$ formed is $\mathrm{HgBrOH}$. This assumes, following Goodsite et al. [2004], that the value of $k_{3, \mathrm{OH}}$ is the same as that of $k_{3, \mathrm{Br}}$ which they explicitly calculated. If reaction (R3) with $\mathrm{OH}$ were insignificant (i.e., $k_{3, \mathrm{OH}}=0$ ) then the global $\mathrm{Hg}^{0}$ lifetime would be $50 \%$ greater, with the largest changes in the lower troposphere.

[14] Our calculations predict rapid summertime oxidation of $\mathrm{Hg}^{0}\left(\tau_{\text {local }}=10-100\right.$ days $)$ at all altitudes in Antarctic summer. Sprovieri et al. [2002] and Temme et al. [2003] have observed high concentrations of gaseous $\mathrm{Hg}$ (II) on the Antarctic coast during November through January; these differ from springtime mercury depletion events in that they observe positive correlations between gaseous $\mathrm{Hg}(\mathrm{II})$ and ozone. As $\mathrm{OH}, \mathrm{O}_{3}$ and other known oxidants of $\mathrm{Hg}^{0}$ could not explain the observed $\mathrm{Hg}(\mathrm{II})$ concentrations, Sprovieri et al. [2002] hypothesized a role for bromine radicals or photochemical oxidants generated immediately above the snowpack. S. Brooks et al. (Antarctic polar plateau snow surface conversion of deposited oxidized mercury to gaseous elemental mercury with fractional long-term burial, submitted to Geophysical Research Letters, 2006) also observed high gaseous $\mathrm{Hg}(\mathrm{II})$ at the South Pole under unstable atmospheric conditions, which they attributed to halogen reactions in the upper troposphere. Our work shows that subsiding air from any part of the troposphere could bring to the surface gaseous $\mathrm{Hg}(\mathrm{II})$, formed by reactions with $\mathrm{Br}$, together with elevated ozone.

[15] Thus far our base case calculations have used one combination of rate constants ( $k_{1}$ from Donohoue et al. [2006]; $k_{3, \mathrm{Br}}, k_{3, \mathrm{OH}}$, and $k_{1}: k_{2}$ from Goodsite et al. [2004]).
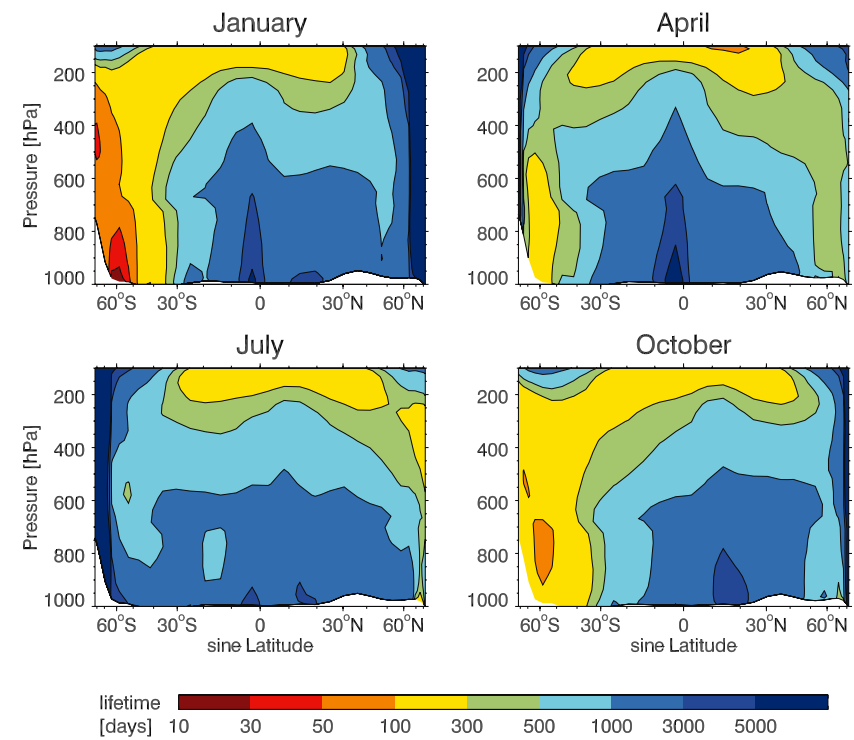

Figure 2. Lifetime [days] of atmospheric $\mathrm{Hg}^{0}$ against oxidation to $\mathrm{Hg}(\mathrm{II})$ by two-step recombination with $\mathrm{Br}$ atoms and $\mathrm{OH}$ (reactions (R1)-(R3) forming $\mathrm{HgBr}_{2}$ or $\mathrm{HgBrOH}$ ), using 'base case' rate constants from Donohoue et al. [2006] and Goodsite et al. [2004] with the bromine distribution shown in Figure 1. The corresponding globalmean tropospheric lifetime of $\mathrm{Hg}^{0}$ is 510 days, assuming a uniform $\mathrm{Hg}^{0}$ mixing ratio. The text describes results with other rate constants from Table 1, all of which yield qualitatively similar distributions of $\mathrm{Hg}^{0}$ lifetime. 
Other theoretical [Khalizov et al., 2003; Goodsite et al., 2004] and experimental [Ariya et al., 2002] estimates of $k_{1}$ are faster (see Table 1), although Donohoue et al. [2006] argue that these values are less accurate. The fastest $k_{1}$ value with reported temperature dependence [Khalizov et al., 2003] implies $\tau_{\text {global }}=160$ days, after recalculating $k_{2}$ to keep the $k_{1}: k_{2}$ balance [Goodsite et al., 2004].

[16] The calculated value of $\tau_{\text {global }}$ also depends on competition between reactions (R2) and (R3). Balabanov et al. [2005] studied reaction (R3) as well as several additional reactions that could occur in the $\mathrm{Hg}-\mathrm{Br}$ system. Their high-pressure limit for $k_{3, \mathrm{Br}}$ is half that of Goodsite et al. [2004]. They also found that abstraction of $\mathrm{Br}$ from $\mathrm{HgBr}$ by reaction (R4) decreases the rate of $\mathrm{Hg}$ (II) formation.

$$
\mathrm{HgBr}+\mathrm{Br} \rightarrow \mathrm{Hg}+\mathrm{Br}_{2}
$$

Calculating the global lifetime of $\mathrm{Hg}^{0}$ against reactions (R1)-(R4) with the high pressure $k_{3}$ and $k_{4}$ values from Balabanov et al. [2005], and other rates the same as our base case, yields $\tau_{\text {global }}=630$ days. Additional oxidants for $\mathrm{HgBr}$ in reaction (R3) suggested by Balabanov et al. [2005], such as $\mathrm{BrO}$ and $\mathrm{Br}_{2}$, would decrease $\tau_{\text {global }}$.

[17] The amount and distribution of tropospheric $\mathrm{Br}$ is a large uncertainty in our lifetime estimates. Our calculations show that in order to have a globally significant impact on $\mathrm{Hg}^{0}$, atomic $\mathrm{Br}$ must be present in the middle and upper troposphere, where cold temperatures suppress the thermal dissociation of $\mathrm{HgBr}$. While global models predict peak $\mathrm{Br}$ concentrations in this region from bromocarbon sources [von Glasow et al., 2004; Yang et al., 2005], observational evidence is indirect and does not clearly resolve the upper troposphere and lowermost stratosphere [Salawitch et al., 2005]. Even in the lowermost stratosphere, atomic Br could significantly shorten the lifetime of $\mathrm{Hg}^{0}$ through relatively rapid air exchange with the troposphere.

[18] In conclusion, oxidation by atomic bromine could result in an atmospheric lifetime of $\mathrm{Hg}^{0}$ against conversion to $\mathrm{Hg}(\mathrm{II})$ of $1.4-1.7$ years, and possibly as short as 0.5 years, with most reaction taking place in the free troposphere. This would be an important, and possibly dominant, global pathway for oxidation and deposition of atmospheric mercury. It could reconcile the atmospheric evidence that $\mathrm{Hg}^{0}$ oxidation is photochemically mediated [Bergan and Rodhe, 2001; Selin et al., 2006] with the evidence against a major role for oxidation by $\mathrm{OH}$ [Calvert and Lindberg, 2005]. The mechanism appears qualitatively consistent with mercury observations - the seasonal cycle of $\mathrm{Hg}^{0}$; airborne particulate mercury measurements; and gaseous $\mathrm{Hg}$ (II) in Antarctic summer - but global CTMs are necessary for more stringent quantitative tests. Improved atmospheric measurements of inorganic bromine and its radicals, particularly in the middle and upper troposphere, are needed. Uncertainties in the kinetic data, especially for reactions involving $\mathrm{HgBr}$ as a reactant, need to be resolved in order to more narrowly constrain the lifetime of $\mathrm{Hg}^{0}$ and the $\mathrm{Hg}(\mathrm{II})$ product distribution.

[19] Acknowledgments. This work was supported by the Atmospheric Chemistry Program of the U.S. National Science Foundation and by the STAR Graduate Fellowship program of the U.S. Environmental Protection Agency (EPA). The EPA has not officially endorsed this publication and the views expressed herein may not reflect those of the EPA.

\section{References}

Ariya, P. A., A. Khalizov, and A. Gidas (2002), Reaction of gaseous mercury with atomic and molecular halogens: Kinetics, product studies, and atmospheric implications, J. Phys. Chem. A, 106, 7310-7320.

Balabanov, N. B., and K. A. Peterson (2003), Mercury and reactive halogens: The thermochemistry of $\mathrm{Hg}+\{\mathrm{Cl}-2, \mathrm{Br}-2, \mathrm{BrCl}, \mathrm{ClO}$, and $\mathrm{BrO}\}$, J. Phys. Chem. A, 107, 7465-7470.

Balabanov, N. B., B. C. Shepler, and K. A. Peterson (2005), Accurate global potential energy surface and reaction dynamics for the ground state of $\mathrm{HgBr} 2$, J. Phys. Chem. A, 109, 8765-8773.

Bergan, T., and H. Rodhe (2001), Oxidation of elemental mercury in the atmosphere: Constraints imposed by global scale modeling, J. Atmos. Chem., 40, 191-212.

Calvert, J. G., and S. E. Lindberg (2004), The potential influence of iodinecontaining compounds on the chemistry of the troposphere in the polar spring: II. Mercury depletion, Atmos. Environ., 38, 5105-5116.

Calvert, J. G., and S. E. Lindberg (2005), Mechanisms of mercury removal by $\mathrm{O}_{3}$ and $\mathrm{OH}$ in the atmosphere, Atmos. Environ., 39, 3355-3367.

Donohoue, D. L., D. Bauer, B. Cossairt, and A. J. Hynes (2006), Temperature and pressure dependent rate coefficients for the reaction of $\mathrm{Hg}$ with $\mathrm{Br}$ and the reaction of $\mathrm{Br}$ with $\mathrm{Br}$ : A Pulsed laser photolysis-pulsed laser induced fluorescence study, J. Phys. Chem. A, 110, 6623-6632.

Ebinghaus, R., H. H. Kock, A. M. Coggins, T. G. Spain, S. G. Jennings, and C. Temme (2002), Long-term measurements of atmospheric mercury at Mace Head, Irish west coast, between 1995 and 2001, Atmos. Environ., $36,5267-5276$.

Fitzenberger, R., H. Bosch, C. Camy-Peyret, M. P. Chipperfield, H. Harder, U. Platt, B. M. Sinnhuber, T. Wagner, and K. Pfeilsticker (2000), First profile measurements of tropospheric BrO, Geophys. Res. Lett., 27(18), $2921-2924$.

Goodsite, M. E., J. M. C. Plane, and H. Skov (2004), A theoretical study of the oxidation of $\mathrm{Hg}-0$ to $\mathrm{HgBr} 2$ in the troposphere, Environ. Sci. Technol., 38(6), 1772-1776.

Hall, B. (1995), The gas phase oxidation of elemental mercury by ozone, Water Air Soil Pollut., 80, 301-315.

Hedgecock, I. M., G. A. Trunfio, N. Pirrone, and F. Sprovieri (2005), Mercury chemistry in the MBL: Mediterranean case and sensitivity studies using the AMCOTS (Atmospheric Mercury Chemistry over the Sea) model, Atmos. Environ., 39, 7217-7230.

Khalizov, A. F., B. Viswanathan, P. Larregaray, and P. A. Ariya (2003), A theoretical study on the reactions of $\mathrm{Hg}$ with halogens: Atmospheric implications, J. Phys. Chem. A, 107, 6360-6365.

Laurier, F. J. G., R. P. Mason, L. Whalin, and S. Kato (2003), Reactive gaseous mercury formation in the North Pacific Ocean's marine boundary layer: A potential role of halogen chemistry, J. Geophys. Res., 108(D17), 4529, doi:10.1029/2003JD003625.

Leser, H., G. Honninger, and U. Platt (2003), MAX-DOAS measurements of $\mathrm{BrO}$ and $\mathrm{NO} 2$ in the marine boundary layer, Geophys. Res. Lett., 30(10), 1537, doi:10.1029/2002GL015811.

Lin, C. J., P. Pongprueksa, S. E. Lindberg, S. O. Pehkonen, and D. Byun (2006), Scientific uncertainties in atmospheric mercury models: I. Model science evaluation, Atmos. Environ., 40, 2911-2928.

Mason, R. P., and G. R. Sheu (2002), Role of the ocean in the global mercury cycle, Global Biogeochem. Cycles, 16(4), 1093, doi:10.1029/ 2001GB001440.

Murphy, D. M., P. K. Hudson, D. S. Thomson, P. J. Sheridan, and J. C. Wilson (2006), Observations of mercury-containing aerosols, Environ. Sci. Technol., 40(10), 3163-3167, doi:10.1021/es052385x.

Pal, B., and P. A. Ariya (2004a), Gas-phase HO-initiated reactions of elemental mercury: Kinetics and product studies, and atmospheric implications, Environ. Sci. Technol., 38(21), 5555-5566.

$\mathrm{Pal}$, B., and P. A. Ariya (2004b), Studies of ozone initiated reactions of gaseous mercury: Kinetics, product studies, and atmospheric implications, Phys. Chem. Chem. Phys., 6, 572-579.

Park, R. J., D. J. Jacob, B. D. Field, R. M. Yantosca, and M. Chin (2004), Natural and transboundary pollution influences on sulfate-nitrate-ammonium aerosols in the United States: Implications for policy, J. Geophys. Res., 109, D15204, doi:10.1029/2003JD004473.

Platt, U., and G. Honninger (2003), The role of halogen species in the troposphere, Chemosphere, 52(2), 325-338.

Platt, U., and C. Janssen (1995), Observation and role of the free radicals $\mathrm{NO}_{3}, \mathrm{ClO}, \mathrm{BrO}$ and $\mathrm{IO}$ in the troposphere, Faraday Discuss., 100, $175-$ 198.

Pundt, I., J. P. Pommereau, M. P. Chipperfield, M. Van Roozendael, and F. Goutail (2002), Climatology of the stratospheric BrO vertical distribution by balloon-borne UV-visible spectrometry, J. Geophys. Res., 107(D24), 4806, doi:10.1029/2002JD002230. 
Raofie, F., and P. Ariya (2004), Product study of the gas-phase BrOinitiated oxidation of $\mathrm{Hg}^{0}$ : evidence for stable $\mathrm{Hg}^{1+}$ compounds, Environ. Sci. Technol., 38, 4319-4326.

Salawitch, R. J. (2006), Atmospheric chemistry-Biogenic bromine, Nature, 439(7074), 275-277.

Salawitch, R. J., D. K. Weisenstein, L. J. Kovalenko, C. E. Sioris, P. O. Wennberg, K. Chance, M. K. W. Ko, and C. A. McLinden (2005), Sensitivity of ozone to bromine in the lower stratosphere, Geophys. Res. Lett., 32, L05811, doi:10.1029/2004GL021504.

Schofield, R., K. Kreher, B. J. Connor, P. V. Johnston, A. Thomas, D. Shooter, M. P. Chipperfield, C. D. Rodgers, and G. H. Mount (2004), Retrieved tropospheric and stratospheric BrO columns over Lauder, New Zealand, J. Geophys. Res., 109, D14304, doi:10.1029/ 2003JD004463.

Schroeder, W. H., and J. Munthe (1998), Atmospheric mercury-An overview, Atmos. Environ., 32, 809-822.

Selin, N. E., D. J. Jacob, R. J. Park, R. Yantosca, S. Strode, L. Jaegle, and D. A. Jaffe (2006), Chemical cycling and deposition of atmospheric mercury: Global constraints from observations, J. Geophys. Res. doi:10.1029/2006JD007450, in press.

Sinnhuber, B. M., et al. (2005), Global observations of stratospheric bromine monoxide from SCIAMACHY, Geophys. Res. Lett., 32, L20810, doi:10.1029/2005GL023839.

Sommar, J., K. Gårdfeldt, D. Strömberg, and X. Feng (2001), A kinetic study of the gas-phase reaction between the hydroxyl radical and atomic mercury, Atmos. Environ., 35, 3049-3054.

Sprovieri, F., N. Pirrone, I. M. Hedgecock, M. S. Landis, and R. K. Stevens (2002), Intensive atmospheric mercury measurements at Terra Nova Bay in Antarctica during November and December 2000, J. Geophys. Res., 107(D23), 4722, doi:10.1029/2002JD002057.

Temme, C., J. W. Einax, R. Ebinghaus, and W. H. Schroeder (2003), Measurements of atmospheric mercury species at a coastal site in the Antarctic and over the south Atlantic Ocean during polar summer, Environ. Sci. Technol., 37, 22-31.

Tossell, J. A. (2003), Calculation of the energetics for oxidation of gasphase elemental $\mathrm{Hg}$ by $\mathrm{Br}$ and $\mathrm{BrO}, J$. Phys. Chem. A, 107, 7804-7808.

Van Roozendael, M., et al. (2002), Intercomparison of BrO measurements from ERS-2 GOME, ground-based and balloon platforms, Adv. Space Res., 29, 1661-1666.

von Glasow, R., R. Sander, A. Bott, and P. J. Crutzen (2002), Modeling halogen chemistry in the marine boundary layer: 1. Cloud-free MBL, J. Geophys. Res., 107(D17), 4341, doi:10.1029/2001JD000942.

von Glasow, R., R. von Kuhlmann, M. G. Lawrence, U. Platt, and P. J. Crutzen (2004), Impact of reactive bromine chemistry in the troposphere, Atmos. Chem. Phys., 4, 2481-2497.

Yang, X., R. A. Cox, N. J. Warwick, J. A. Pyle, G. D. Carver, F. M. O'Connor, and N. H. Savage (2005), Tropospheric bromine chemistry and its impacts on ozone: A model study, J. Geophys. Res., 110, D23311, doi:10.1029/2005JD006244.

C. D. Holmes and D. J. Jacob, Department of Earth and Planetary Sciences and Division of Engineering and Applied Sciences, Harvard University, Pierce Hall, 29 Oxford Street, Cambridge, MA 02168, USA. (cdh@io.harvard.edu)

X. Yang, Centre for Atmospheric Science, University of Cambridge, Cambridge, UK. 